\title{
Pembelajaran TAI dengan Open Ended Problem untuk Meningkatkan Kemampuan Berpikir Kritis Mahasiswa Tadris Matematika IAIN Curup
}

\author{
Nilna Ma'Rifah ${ }^{1}$, Wahyu Widada ${ }^{2}$ \\ ${ }^{1}$ Mahasiswa S2 Pendidikan Matematika Universitas Bengkulu \\ ${ }^{2}$ Dosen Pascasarjana Pendidikan Matematika Universitas Bengkulu \\ nilnamarifah@gmail.com; w.widada@unib.ac.id
}

\begin{abstract}
ABSTRAK
Penelitian ini bertujuan untuk mengetahui cara menerapkan Pembelajaran Kooperatif tipe Team Assisted Individualization (TAI) menggunakan Soal Open Ended, sehingga terjadi peningkatan kemampuan berpikir kritis mahasiswa IAIN Curup. Jenis penelitian yang dilaksanakan adalah penelitian tindakan kelas (PTK). dengan teknik pengumpulan data menggunakan tes kemampuan berpikir kreatif dan berpikir kritis. Subjek dalam penelitian ini adalah mahasiswa Tadris Matematika Semester III IAIN Curup. Hasil penelitian menunjukan Pembelajaran Kooperatif tipe Team Assisted Individualization (TAI) menggunakan Soal Open Ended, dapat meningkatkan kemampuan berpikir kritis. Kemampuan berpikir kritis ditingkatkan dengan cara membentuk kelompok baru dengan berdasarkan hasil tes Kemampuan berpikir kritis, memberikan pengurangan nilai jika mahasiswa menyalin lembar jawaban dan tidak mengerjakan soal sesuai tipe,menentukan tipe soal yang dikerjakan oleh mahasiswa dan mahasiswa wajib memberikan tanda tangan seteleh mengecek jawaban mahasiswa, memberikan lembar jawaban untuk kelompok yang telah mengerjakan Soal 4 tipe di tahap pengecekan, menginformasikan perwakilan kelompok pada tahap Teaching group ditentukan dengan acak sehingga setiap anggota mempersiapkan diri untuk belajar menjelaskan dan menguasai materi. Peningkatan tes kemampuan berpikir kritis mahasiswa dari Siklus I hingga Siklus II yaitu: 67,78;84,706.
\end{abstract}

Kata kunci: Kemampuan berpikir Kritis, Team Assisted Individualization (TAI), Soal open ended

\section{Pendahuluan}

Matematika sebagai salah satu mata pelajaran di sekolah memegang peranan penting untuk membentuk siswa menjadi berkualitas karena matematika merupakan suatu sarana berpikir untuk mengkaji sesuatu secara logis dan sistematis. Proses pembelajaran matematika juga membutuhkan kemampuan kognitif tingkat tinggi, seperti kemampuan analisis, sintesis dan aluasi, tidak hanya sekedar ingatan pengetahuan faktual ataupun aplikasi sederhana dari berbagi formula. Pada perkembangan zaman sekarang dan masa mendatang peranan matematika semakin dirasakan terutama dalam menyelesaikan masalah-masalah nyata yang dihadapi masyarakat dalam kehidupan sehari-hari.

Nilna Ma'Rifah, Wahyu Widada. (2019). Pembelajaran TAI dengan Open Ended Problem untuk Meningkatkan Kemampuan Berpikir Kritis Mahasiswa Tadris Matematika IAIN Curup. JPMR 4 (1) 
Menyadari pentingnya matematika, maka belajar matematika seharusnya menjadi kebutuhan dan kegiatan yang menyenangkan. Pembelajaran matematika juga bertujuan agar siswa mampu menggunakan penalaran pada pola dan sifat, mengajukan dugaan, memberi alasan atau bukti atau menjelaskan gagasan dan pernyataan matematika. dengan kata lain, belajar matematika tidak terlepas dari kemampuan berpikir kritis.

Pembelajaran berdasarkan teori kognitif didefinisikan sebagai proses belajar yang dibangun oleh guru untuk mengembangkan kreativitas berpikir yang dapat meningkatkan kemampuan siswa dalam mengonstruksi pengetahuan baru sebagai upaya meningkatkan penguasaan yang baik terhadap materi pembelajaran (Abidin,2014:1). Menurut Suherman Dkk (2003:8) proses pembelajaran adalah proses sosialisasi individu siswa dengan lingkungan sekolah, seperti guru, sumber/ fasilitas dan teman sesama siswa. Menurut Sudjana (2001:8) pembelajaran dapat diberi arti sebagai upaya yang sistematik dan disengaja oleh pendidik untuk menciptakan kondisi-kondisi agar peserta didik melakukan kegiatan belajar. Dari pendapat di atas dapat disimpulkan bahwa pembelajaran adalah serangkaian aktivitas untuk meningkatkan kemampuan dan penguasaan materi siswa dengan melibatkan interaksi edukatif antara siswa lain dan gurunya.

Salah satu aplikasi dalam pembelajaran adalah pembelajaran matematika. Pembelajaran matematika merupakan kegiatan pembelajaran yang menekankan kemampuan seseorang dalam memecahkan masalah matematika. Hal ini didukung oleh pendapat Ibrahim dan Suparni ( 2009: 35) yang menyatakan materi matematika merupakan materi yang abstrak yang memiliki karakteristik berbeda dengan ilmu lainnya sehingga, menuntut kemampuan penalaran dalam mempelajarinya dalam kaitan ini belajar matematika secara keseluruhan merupakan belajar memecahkan masalah.

Pembelajaran kooperatif pada prinsipnya terdiri atas empat tahap yaitu penjelasan materi, belajar dalam kelompok, penilaian dan pengakuan tim (Sanjaya,2006:246). Adapun langkah-langkah pembelajaran Team Assisted Individualization (TAI) yang peneliti adaptasi dari komponen-komponen pembelajaran Team Assisted Individualization (TAI) oleh Shoimin (2014:201-202) yaitu :

Tabel 1 Sintaks Assisted Individualization (TAI)

\begin{tabular}{|c|c|}
\hline Fase & Kegiatan \\
\hline $\begin{array}{l}\text { Fase } 1 \\
\text { Tes Penempatan (Placement } \\
\text { Test) }\end{array}$ & $\begin{array}{l}\text { Guru memberikan soal pretest kepada siswa } \\
\text { untuk menentukan skor dasar siswa atau } \\
\text { mencermati rata-rata nilai harian pada bab } \\
\text { sebelumnya yang diperoleh siswa }\end{array}$ \\
\hline $\begin{array}{l}\text { Fase } 2 \\
\text { Pembagian } \\
(\text { Teams })\end{array}$ & $\begin{array}{l}\text { Siswa dibagikan kedalam kelompok } \\
\text { beranggotakan 3-4 siswa. }\end{array}$ \\
\hline $\begin{array}{l}\text { Fase } 3 \\
\text { Kelompok Pengajaran } \\
\text { (Teaching Group) }\end{array}$ & $\begin{array}{l}\text { Guru memberikan pengajaransecara singkat } \\
\text { menjelang pemberian tugas kelompok. }\end{array}$ \\
\hline
\end{tabular}

Nilna Ma'Rifah, Wahyu Widada. (2019). Pembelajaran TAI dengan Open Ended Problem untuk Meningkatkan Kemampuan Berpikir Kritis Mahasiswa Tadris Matematika IAIN Curup. JPMR 4 (1) 


\begin{tabular}{|c|c|}
\hline $\begin{array}{l}\text { Fase } 4 \\
\text { Student Creative }\end{array}$ & $\begin{array}{l}\text { Guru memberikan tugas kepada siswa berupa } \\
\text { LKS dalam kelompok dengan setiap anggota } \\
\text { memperoleh tipe berbeda serta menciptakan } \\
\text { situasi dimana keberhasilan individu } \\
\text { ditentukan atau dipengaruhi oleh } \\
\text { keberhasilan kelompok. }\end{array}$ \\
\hline $\begin{array}{l}\text { Fase } 5 \\
\text { Belajar Kelompok } \quad \text { (Team } \\
\text { Study) }\end{array}$ & $\begin{array}{l}\text { 1. Siswa bersama mengerjakan tugas-tugas } \\
\text { dari LKS yang diberikan secara } \\
\text { bertahap. }\end{array}$ \\
\hline & $\begin{array}{l}\text { 2. Siswa bersama-sama mendiskusikan } \\
\text { jawaban soal pada LKS pada tahap } \\
\text { pertama. } \\
\text { 3. Siswa mengerjakan soal sesuai dengan } \\
\text { tipe yang diperoleh pada LKS secara } \\
\text { individual. } \\
\text { 4. Siswa saling mengecek jawaban dengan } \\
\text { aturan siswa yang memperoleh soal tipe } \\
\text { A mengecek jawaban soal tipe B dan } \\
\text { sebaiknya serta Siswa yang memperoleh } \\
\text { soal tipe C mengecek jawaban soal tipe } \\
\text { D dan sebaliknya. } \\
\text { Guru memberikan bantuan secara } \\
\text { individual kepada siswa yang } \\
\text { membutuhkan dengan dibantu siswa } \\
\text { yang memiliki kemampuan akademis } \\
\text { yang bagus di dalam kelompok yang } \\
\text { berperan sebagai tutor sebaya. }\end{array}$ \\
\hline $\begin{array}{l}\text { Fase } 6 \\
\text { Fact Test }\end{array}$ & $\begin{array}{l}\text { Guru memberikan tes kepada siswa atas fakta } \\
\text { yang diperoleh siswa }\end{array}$ \\
\hline $\begin{array}{l}\text { Fase } 7 \\
\text { Skor tim dan rekognisi tim } \\
\text { (Team Score and Team } \\
\text { Recognition) }\end{array}$ & $\begin{array}{l}\text { Guru menghitung skor tim dan menentukan } \\
\text { kelompok terbaik sampai kelompok yang } \\
\text { kurang berhasil }\end{array}$ \\
\hline $\begin{array}{l}\text { Fase } 8 \\
\text { Unit Seluruh Kelas (Whole } \\
\text { Class Unit) }\end{array}$ & $\begin{array}{l}\text { Gurumembahas materi yang } \\
\text { dipahami dan bersama-sama } \\
\text { menarik } \\
\text { kesimpulan pembelajaran. }\end{array}$ \\
\hline
\end{tabular}

Berpikir merupakan salah satu aktivitas mental yang tidak dapat dipisahkan dari kehidupan manusia. Kemampuan berpikir kritis setiap individu berbeda antara satu dengan lainnya sehingga perlu dipupuk sejak dini. Berpikir terjadi dalam setiap aktivitas mental manusia berfungsi untuk memformulasikan atau menyelesaikan masalah, membuat keputusan serta mencari alasan.

Nilna Ma'Rifah, Wahyu Widada. (2019). Pembelajaran TAI dengan Open Ended Problem untuk Meningkatkan Kemampuan Berpikir Kritis Mahasiswa Tadris Matematika IAIN Curup. JPMR 4 (1) 
Berpikir kritis adalah sebuah proses sistematis yang memungkinkan siswa untuk merumuskan dan mengevaluasi keyakinan dan pendapat mereka sendiri. Berpikir kritis adalah sebuah proses terorganisasi yang memungkinkan siswa mengevaluasi bukti, asumsi, logika dan bahasa yang mendasari pernyataan orang lain. Berpikir kritis juga merupakan berpikir dengan baik, dan merenungkan tentang proses berpikir merupakan bagian dari berpikir dengan baik (Fitriawati, 2010:36). Ada beberapa definisi Menurut John Chaffe, berpikir kritis didefinisikan sebagai berpikir untuk menyelidiki secara sistematis proses berpikir itu sendiri. Maksudnya tidak hanya memikirkan dengan sengaja, tetapi juga meneliti bagaimana kita dan orang lain menggunakan bukti dan logika. (Johnson, 2010:187). Indikator Kemampuan Berpikir Kritis Matematis terdiri atas :

Tabel 2 Indikator Kemampuan Berpikir Kritis Matematis

\begin{tabular}{|c|l|}
\hline Nomor & \multicolumn{1}{|c|}{ Indikator Kemampuan Berpikir Kritis Matematis } \\
\hline 1 & Mengidentifikasi asumsi yang diberikan (Elementary Clarification) \\
\hline 2 & Keterampilan mengenal dan memecahkan masalah \\
\hline 3 & Kesimpulan (Inference) \\
\hline
\end{tabular}

Untuk mencapai indicator berpikir kritis, mahasiswa dapat men=menfaatkan media kontekstual Menurut (Widada, 2015) contextual learning media can effectively produce a pattern by which, with the teacher or friend guidance, the students can easily develop conjecture and perform vertical mathematization (Jumri, Widada, \& Herawaty, 2018). Pemanfaatan media pembelajaran kontekstual yang tepat dan sesuai dengan kebutuhan, dapat meningkatkan kemampuan siswa dalam proses pencapaian konsep dan prinsip matematika serta meningkatkan ketuntasan belajar siswa; Media pembelajaran kontekstual dapat dengan efektif menghasilkan pola (pattern) yang dapat dengan mudah siswa menyusun peryataan awal (conjecture) dan dengan aktivitas matematisasi vertikal, siswa dengan bantuan teman yang lebih mampu atau guru dapat mencapai konsep dan prinsip yang sedang mereka pelajari; Lebih dari $82 \%$ siswa mampu mencapai konsep dan prinsip dengan benar; Ada 78\% siswa mampu menyusun definisi dan teorema dengan tepat; Rerata tingkat ketuntasan belajar mencapai sebesar 86,5\%; Ditemukan $14 \%$ peserta didik yang mampu meningkat sejauh tiga level perkembangan kognitif (dari Level Intra meningkat ke Level Semi-trans dalam Pelevelan Extended Triad-Level++) (Widada, 2015).

\section{Metode}

Bentuk penelitian yang digunakan adalah Penelitian Tindakan Kelas (PTK) menurut Paizaluddin ( 2014 : 67 ) adalah sebagai berikut: Penelitian tindakan merupakan suatu pencarian sistematis yang dilaksanakan oleh pelaksana program dalam kegiatannya sendiri, dalam mengumpulkan data tentang pelaksanaan kegiatan, keberhasilan dan hambatan yang dihadapi untuk menyusun rencana dan melakukan kegiatan penyempurnaan (Sukmadinata, 2005:140). Subjek dari penelitian tindakan kelas ini adalah mahasiswa Tadris Matematika IAIN Curup

Nilna Ma'Rifah, Wahyu Widada. (2019). Pembelajaran TAI dengan Open Ended

Problem untuk Meningkatkan Kemampuan Berpikir Kritis Mahasiswa Tadris

Matematika IAIN Curup. JPMR 4 (1) 
tahun ajaran 2018/2019 dengan jumlah mahasiswa 17. Peneliti memilih mahasiswa semester III sebagai subjek penelitian karena berdasarkan penempatan PIPM dan atas saran dosen. Alat yang digunakan untuk mengukur kemampuan berpikir kritis dalam proses pembelajaran.

\section{Hasil Dan Pembahasan}

Penelitian ini bertujuan untuk mengetahui cara menerapkan pembelajaran kooperatif tipe Team Assisted Individualization (TAI) menggunakan soal Open Ended agar dapat meningkatkan Berpikir Kritis mahasiswa Tadris Matematika IAIN Curup. Hasil Penelitian Menunjukan peningkatan kemampuan berpikir kritis mahasiswa meningkat pada setiap siklus. Nilai rata-rata mahasiswa pada siklus I adalah 67,78 adapun jumlah mahasiswa yang memperoleh nilai $\geq 80$ adalah 1 . Karena, nilai rata-rata mahasiswa pada siklus I $\leq 80$ maka, pembeljaran belum tercapai. Pada siklus II nilai rata-rata mahasiswa adalah 84,706 adapun jumlah mahasiswa yang memperoleh nilai $\geq 80$ adalah 11. Sehingga pada siklus II pembelajaran tercapai karena telah sesuaidengan indikator kerberhasilan.

Berdasarkan indikator kemampuan berpikir kritis matematis mahasiswa diberikan tes dengan tipe Open Ended dengan diberikan kepada 17 orang mahasiswa. Tes diberikan ketika tes siklus I yang terdiri dari 2 soal dan tes Siklus II yang terdiri dari 4 soal. Tujuan diberikan Tes untuk mengatahui kemampuan berpikir kritis siswa setelah diterapkan pembelajaran TAI. Peningkatan jumlah mahasiswa pada indikator kemampuan berpikir kritis dapat dilihat pada Tabel 3.

Tabel 3 Indikator Kemampuan Berpikir Kritis

\begin{tabular}{|c|c|c|c|}
\hline Ketentuan & Kategori & $\begin{array}{c}\text { Jumlah Mahasiswa } \\
\text { Siklus I }\end{array}$ & $\begin{array}{c}\text { Jumlah } \\
\text { Mahasiswa } \\
\text { Siklus II }\end{array}$ \\
\hline $90 \leq x \leq 100$ & Sangat baik & 1 & 5 \\
\hline $80 \leq x<90$ & Baik & 1 & 6 \\
\hline $70 \leq x<80$ & Cukup & 6 & 6 \\
\hline $60 \leq x<70$ & Kurang & 9 & 0 \\
\hline$x<60$ & Sangat kurang & 0 & 0 \\
\hline
\end{tabular}

Secara Visual perbandingan mahasiswa yang menempati kelima kategori tersebut dapat dilihat pada diagram berikut 


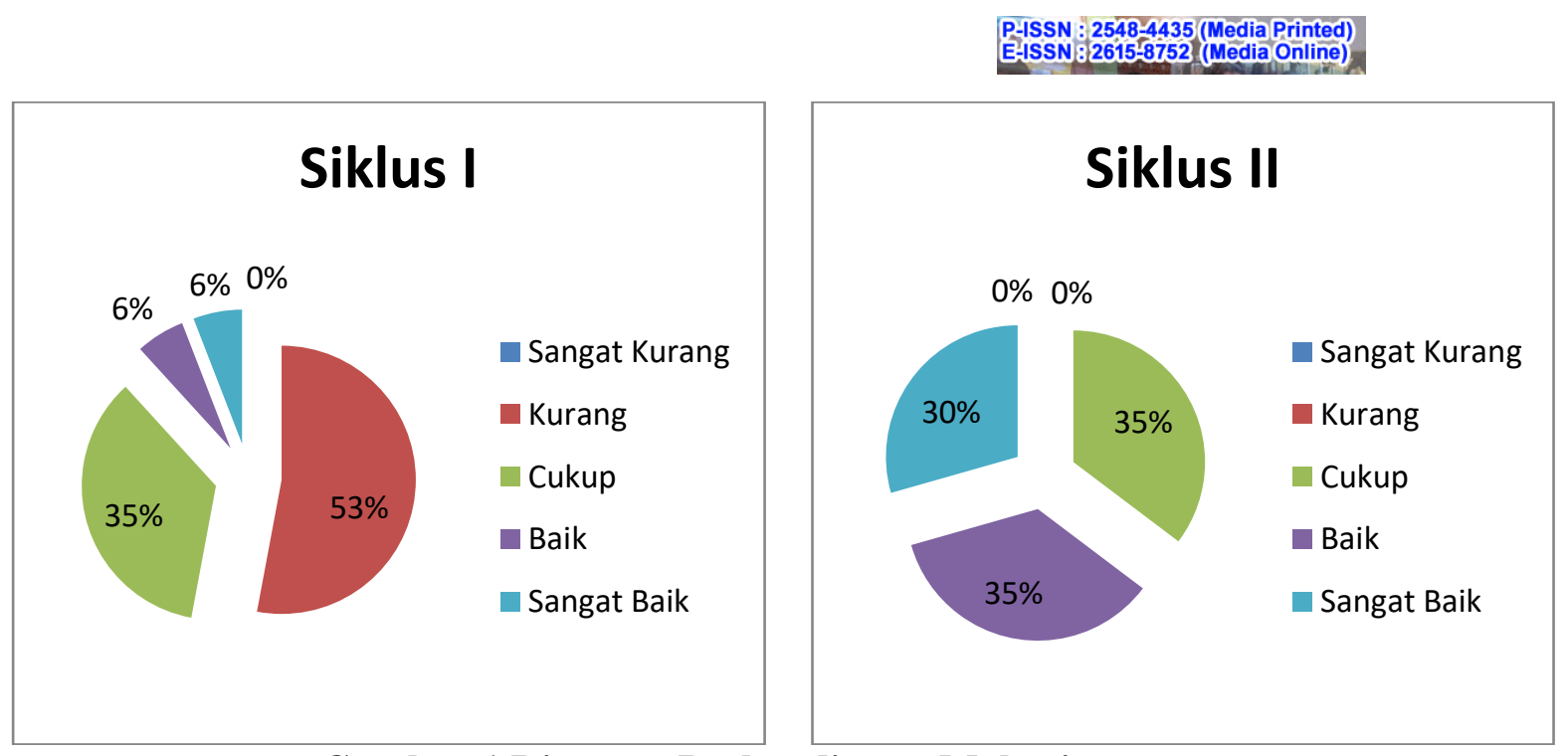

Gambar 1 Diagram Perbandingan Mahasiswa

Berdasarkan Pengolahan data, diketahui bahwa kemampuan berpikir kritis mahasiswa pada mata kuliah Geometri analitik pada siklus I berada pada kategori Kurang. Pada siklus II kemampuan berpikir Kritis meningkat menjadi Baik kemudia disusul oleh kemampuan berpikirkreatif dengan kategori kurang dan cukup. Rata-Rata yang diperoleh siswa pada siklus I adalah sebesar 67,22. Nilai maksimal yang diperoleh siswa adalah 93 dan nilai minimal siswa adalah 62 . Kondisi ini mengalami peningkatan di Siklus II dimana, Nilai rata-rata menjadi 86,112 . Perolehan nilai tersebut menunjukan bahwa peningkatan kemampuan berpikir kritis mahasiswa meningkat cukup tinggi.

Berdasarkan aspek indikator kemampuan berpikir kritis yang terdiri atas Elementary Clarification, Keterampilan mengenal dan memecahkan masalah dan Inference mengalami peningkatan dari siklus sebelumnya, data disajikan pada Tabel 4.

Tabel 4 Peningkatan Kemampuan Berpikir Kritis

\begin{tabular}{|l|c|c|c|c|}
\hline \multicolumn{1}{|c|}{$\begin{array}{c}\text { Aspek-Aspek } \\
\text { Kemampuan } \\
\text { Berpikir Kritis }\end{array}$} & $\begin{array}{c}\text { Rata-rata } \\
\text { Siklus I }\end{array}$ & Kategori & $\begin{array}{c}\text { Rata-Rata } \\
\text { Siklus II }\end{array}$ & Kategori \\
\hline $\begin{array}{l}\text { Elementary } \\
\text { Clarification }\end{array}$ & 65,42 & Cukup & 80,15 & Baik \\
\hline $\begin{array}{l}\text { Keterampilan } \\
\text { mengenal dan } \\
\text { memecahkan } \\
\text { masalah }\end{array}$ & 70,12 & Baik & 83,48 & Baik \\
\hline Inference & 65,27 & Cukup & 70,65 & Baik \\
\hline
\end{tabular}

Persentase kemampuan Elementary Clarification yang ditunjukan dengan menulis diketahui maupun yang ditanyakan soal dengan tepat dalam kategori Cukup pada siklus I dengan nilai 65,42 dan mengalami peningkatan menjadi kategori baik pada siklus II dengan rata-rata 80,15. Hal ini disebabkan mahasiswa mulai terbiasa belajar menggunakan TAI dan terlatih menggunakan soal Open

Nilna Ma'Rifah, Wahyu Widada. (2019). Pembelajaran TAI dengan Open Ended

Problem untuk Meningkatkan Kemampuan Berpikir Kritis Mahasiswa Tadris

Matematika IAIN Curup. JPMR 4 (1) 
ended . Pola pengerjaan dalam Rai dalam katagori belajar kelompok juga melatih mahasiswa untuk menelaah apa yang diketahui soal baru mencari jawaban soal.

Kemampuan mengenal dan memecahkan masalah yang diberikan dalam soal yang ditunjukan dengan membuat model matematika dengan tepat dan memberi penjelasan dengan tepat pada sub bab materi irisan kerucut. Siklus I dan Siklus II untuk indikator ini berada pada kategori baik serta dengan peningkatan rata-rata sebesar 13,36. Hal ini terjadi dikarenak pada soal siklus II lebih menekan kan pada pengamalan rumus dan mahasiswa berpikir kritis dalam menentukan titiktitik yang terdapat pada garis singgung. Penerapan Tai juga membuat siswa terlati menjawab dan mejelaskan karena, sebelumnya telah terdapat tahap-tahap pengerjaan soal Open Ended. Presentase kemampuan membuat kesimpulan dengan tepat awalnya untuk Siklus I berada pada kategori kurang dan meningkat menjadi kategori Baik pada Siklus II. Kondisi ini menunjukan bahwa Pembelajaran Kooperatif tipe Team Assisted Individualization (TAI) menggunakan Soal Open Ended agar dapat meningkatkan Kemampuan Berpikir Kritis. Hasil penelitian ini mendukung penelitian lain seperti: melalui pembelajaran kelompok heterogen meningkatkan kemampuan matematik siswa yang dideskripsikan dalam dekomposisi genetiknya (Widada, 2002)(Widada, 2004), juga pembelajaran turunan bagi mahasiswa pendidikan matematika (Widada \& Herawaty, 2017). Dengan demikian, maka pembelajaran kooperatif di perguruan tinggi dapat dijadikan alternative positif dalam upaya meningkatkan kemampuan matematis mahasiswa.

\section{Simpulan}

Berdasarkan hasil penelitian yang telah dilakukan di Tadris Matematika IAIN Curup Semester III diperoleh penerapan Pembelajaran Kooperatif tipe Team Assisted Individualization (TAI) menggunakan Soal Open Ended agar dapat meningkatkan Kemampuan berpikir kritis dengan cara :

a. Dosen model sering bertanya kepada salah satu anggota kelompok tentang jawaban dari soal open ended yang diperoleh pada saat mengerjakan Lembar Tugas di Student Creative dan belajar kelompok.

b. Dosen model memberikan pengurangan nilai jika mahasiswa menyalin lembar jawaban dan tidak mengerjakan soal sesuai tipe.

c. Dosen model menentukan tipe soal yang dikerjakan oleh mahasiswa dan mahasiswa wajib memberikan tanda tangan seteleh mengecek jawaban mahasiswa.

d. Dosen model hanya memberikan lembar jawaban untuk kelompok yang telah mengerjakan soal 4 tipe di tahap pengecekan.

e. Dosen model menginformasikan perwakilan kelompok pada tahap Teaching group ditentukan dengan acak sehingga setiap anggota mempersiapkan diri untuk belajar menjelaskan dan menguasai materi.

Kegiatan tersebut terbukti dapat meningkatkan kemampuan berpikir kreatif dan berpikir kritis dari siklus I sampai Siklus II. Nilai akhir Siklus I

Nilna Ma'Rifah, Wahyu Widada. (2019). Pembelajaran TAI dengan Open Ended Problem untuk Meningkatkan Kemampuan Berpikir Kritis Mahasiswa Tadris Matematika IAIN Curup. JPMR 4 (1) 
menunjukan rata-rata mahasiswa 67,78 , kemudian pada Siklus II nilai tes meningkat dengan rata-rata 84,706.

\section{Daftar Pustaka}

Abidin, Yunus. (2014). Desain Sistem Pembelajaran dalam Konteks Kurikulum 2013. Bandung : PT Refika Aditama.

Ermalinda, Paizaluddin. 2014. Penelitian Tindakan Kelas: (Classroom Action. Research) Panduan Teoritis dan Praktis. Bandung: Alfabeta. Hamalik, Oemar.

Fitriawati, Nina. (2010) Penerapan model Pembelajran Berbasis Masalah (Problem Based Learning) Dalam Meningkatkan Kemampuan Berpikir Kritis Siswa Pada Mata Pelajaran IPS Terpadu Kelas VIII Di MTsN Selorejo Blitar.(UIN Maulana Malik Ibrahim Malang.)

Ibrahim \& Suparni. (2009). Strategi Pembelejaran Matematika. Yogyakarta : Teras.

Johnson, Elaine B. (2010). Contextual Teaching and Learning : Menjadikan Kegiatan Belajar Mengajar Mengasyikkan dan Bermakna. Bandung: Kaifa

Jumri, R., Widada, W., \& Herawaty, D. (2018). Improving the Innovation of Mathematics Education Undergraduate through Cooperative Learning. International Journal of Science and Research (IJSR), 7(2), 2016-2019. https://doi.org/10.21275/ART201818

Munandar, Utami. (2009). Pengembangan Kreatifitas Anak Berbakat. Jakarta : Rineka Cipta

Sanjaya, Wina. (2006). Strategi Pembelajaran Berorientasi Standar Proses Pendidikan. Jakarta : Kencana

Shoimin, Aris. (2014). 68 Model Pembelajaran Inovatif dalam Kurikulum 2013. Yogyakarta : AR-RUZZ MEDIA.

Sudjana. (2001). Metode \& Teknik Pembelajaran Partisipatif. Bandung : Falah Production.

Suherman dkk. (2003). Strategi Pembelejaran Matematika Kontemporer. FKIP Matematika UPI.

Sukmadinata, Nana Syaodih. (2005). Metode Penelitian Pendidikan. Bandung : PT Remaja Rosdakarya.

Widada, W. (2002). Teori APOS sebagai Suatu Alat Analisis Dekomposisi Genetik terhadap Perkembangan Konsep Matematika Seseorang. Journal of Indonesian Mathematicel Society (MIHMI), 8(3).

Widada, W. (2004). Pendekatan Pembelajaran Matematika Berbasis Masalah. Surabays: Unipa Press.

Widada, W. (2015). Proses Pencapaian Konsep Matematika dengan Memanfaatkan Media Pembelajaran Kontekstual. Jurnal Penelitian Pendidikan Matematika Dan Sains, 22(1), 31-44. Retrieved from https://id.wikipedia.org/wiki/Pembelajaran

Widada, W., \& Herawaty, D. (2017). Dekomposisi Genetik tentang Hambatan

Nilna Ma'Rifah, Wahyu Widada. (2019). Pembelajaran TAI dengan Open Ended Problem untuk Meningkatkan Kemampuan Berpikir Kritis Mahasiswa Tadris Matematika IAIN Curup. JPMR 4 (1) 
Jurnal Pendidikan Matematika Raflesia

Vol. 04 No. 01, Juni 2019

https://ejournal.unib.ac.id/index.php/jpmr

P-ISSN : 2548-4435 (Media Printed) E-ISSN :2615-8752 (Media Online)

Mahasiswa dalam Menerapkan Sifat-sifat Turunan. Jurnal Didaktik

Matematika, 4(2), 136-151. https://doi.org/10.24815/jdm.v4i2.9216

Nilna Ma'Rifah, Wahyu Widada. (2019). Pembelajaran TAI dengan Open Ended Problem untuk Meningkatkan Kemampuan Berpikir Kritis Mahasiswa Tadris Matematika IAIN Curup. JPMR 4 (1) 